\title{
Paideusis
}

\section{Socratic Open-mindedness}

\section{William Hare}

Volume 18, Number 1, 2009

URI: https://id.erudit.org/iderudit/1072334ar

DOI: https://doi.org/10.7202/1072334ar

See table of contents

Publisher(s)

Canadian Philosophy of Education Society

ISSN

0838-4517 (print)

1916-0348 (digital)

Explore this journal

Cite this article

Hare, W. (2009). Socratic Open-mindedness. Paideusis, 18(1), 5-16.

https://doi.org/10.7202/1072334ar
Article abstract

A philosophical conception of open-minded inquiry first emerges in western philosophy in the work of Socrates. This paper develops an interpretation of Socratic open-mindedness drawing primarily on Socratic ideas about (i) the requirements of serious argument, and (ii) the nature of human wisdom. This account is defended against a number of objections which mistakenly interpret Socrates as defending, teaching, or inducing skepticism, and neglecting the value of expert wisdom. The ongoing significance of Socratic open-mindedness as an ideal of inquiry is brought out through examination of a notorious Canadian case in the context of forensic pathology.
This document is protected by copyright law. Use of the services of Erudit (including reproduction) is subject to its terms and conditions, which can be viewed online.

https://apropos.erudit.org/en/users/policy-on-use/ 


\title{
Socratic Open-mindedness
}

\author{
WILLIAM HARE \\ Mount Saint Vincent University
}

\begin{abstract}
A philosophical conception of open-minded inquiry first emerges in western philosopby in the work of Socrates. This paper develops an interpretation of Socratic open-mindedness drawing primarily on Socratic ideas about (i) the requirements of serious argument, and (ii) the nature of human wisdom. This account is defended against a number of objections which mistakenly interpret Socrates as defending, teacbing, or inducing skepticism, and neglecting the value of expert wisdom. The ongoing significance of Socratic openmindedness as an ideal of inquiry is brought out through examination of a notorious Canadian case in the context of forensic pathology.
\end{abstract}

\section{Introduction}

To have arrived at a dogmatic and unyielding position is to be seriously incapacitated and constrained. We are liable to reject contrary arguments out of hand, fail to examine alternative proposals and suggestions in an unbiased manner, and adhere blindly to a given position. Our outlook amounts to a closed-minded attitude which dismisses further inquiry, reflection, and discussion as pointless, thereby reaching a stubbornly inflexible position in which beliefs are viewed as fixed and final beyond all possibility of critical and open-minded review. With minds closed, we cannot in the end even entertain the thought that there might be a different and perhaps better way of thinking about a certain matter. Unable to conceive of the possibility that there might be an alternative view worthy of serious consideration, evidence is ignored, explained away, and sometimes suppressed, allowing one's present views to remain sheltered from any kind of critical scrutiny. A sincere concern for truth is replaced by a determination to protect whatever one now takes to be true.

Whatever inclination we may once have had, or might have had, to take reasons and evidence into account in forming or revising our ideas disappears, with the result that what John Stuart Mill calls that steady habit of correcting our opinions through a critical comparison with the views of others is gradually eroded (Mill, 1977, 80). An unshakable certainty in the rightness of our position begins to settle in, typically accompanied by intellectual arrogance. If David Hume is right, such closedmindedness is all too common: "The greater part of mankind are naturally apt to be affirmative and dogmatical in their opinions; and while they see objects only on one side, and have no idea of any counterpoising argument, they throw themselves precipitately into the principles, to which they are inclined; nor have they any indulgence for those who entertain opposite sentiments" (Hume, 1955, 188). By inhibiting intellectual development, preventing us from recognizing mistakes, and interfering with our ability to learn, such attitudes conflict with the central purposes of education.

In view of these dangers, we might well look to philosophy for an account of the positive ideal of open-mindedness, since an ideal is capable of inspiring and guiding us in a certain direction by revealing to us the shortcomings in our present efforts, in this case with respect to belief formation and

(C) Copyright 2009. The author, William Hare, assigns to Paideusis the right of first publication and educational and non-profit institutions a non-exclusive license to use this document for personal use and in courses of instruction provided that the article is used in full and this copyright statement is reproduced. Any other usage is probibited without the express permission of the author. 
revision. In western philosophy, a perspective on open-mindedness first emerges clearly with Socrates, I believe, and the approach he championed is a powerful demonstration of the ideal at work. Socratic open-mindedness still resonates in our thinking and is capable of giving valuable guidance if we can learn from the lessons it has to offer. As concerns education, for example, it is particularly valuable in showing how open-mindedness can influence the practice of teaching and foster an approach to learning which involves critical reflection. More generally, the Socratic account is helpful in understanding how open-mindedness relates to skepticism, belief, knowledge, and expertise, connections that continue to prove puzzling and invite philosophical discussion (Hare, 2009).

In one of the last pieces he wrote before he died in 2007, Richard Rorty declares: "I am all for rationality - for Socratic open-mindedness and willingness to hear the other side" (Rorty, 2007). Rorty's own view about the value of open-mindedness (Rorty, 1989, 52) differs from the one I defend in what follows, but it is not difficult to understand in a general way what Rorty has in mind when he speaks of Socratic open-mindedness. The phrase conjures up a certain conception of the ideal implicit in several Socratic remarks and observations; and it also brings to mind a vivid example of the ideal of openmindedness as a guiding principle in Socratic dialogue and conversation. As we shall see, however, not everyone is ready to associate the ideal of open-mindedness with Socrates, whether we have in mind Socratic philosophy or Socratic practice.

\section{Open-minded Inquiry}

Open-mindedness is an intellectual virtue and educational ideal that involves being receptive in a critical manner to new ideas and to ideas that conflict with one's own beliefs; without a critical component, there would be no contrast with credulity and open-mindedness would be no virtue at all. Openminded inquiry is characterized by a readiness to attend seriously to every finding and every interpretation that may be relevant to forming a sound judgment or revising one's view. It involves a willingness to give consideration to further evidence that may yet emerge, recognizing that such further evidence may require revising previous conclusions that had seemed settled. Open-mindedness is particularly striking and commendable when we overcome resistance within ourselves to certain ideas, when we are prepared to expose our own judgments about what is true to criticism, and when we are determined to abide by the results of an impartial and unprejudiced investigation in the interests of truth (Hare, 2007).

This suggests that open-minded inquiry is closely akin to what Susan Haack calls genuine inquiry, namely the kind of disinterested examination that seeks the truth regardless of what the truth may turn out to be; and it contrasts in the sharpest manner with pseudo-inquiry where, as Haack puts it, a case is simply made for a truth that has already been accepted and is not going to be challenged. The genuine inquirer, in Haack's words, "will be willing to go with the evidence even to unpopular conclusions" (Haack, 1997, 38). Elsewhere, she observes that "really inquiring into a question requires that you want to find the true answer" (Haack, 2005, 364). Open-mindedness is also related to the trait Israel Scheffler labels 'reasonableness', the aim of which is "to liberate the mind from dogmatic adherence to prevalent ideological fashions, as well as from the dictates of authority" (Scheffler, 1983, 315). More generally, the open-minded outlook seeks to avoid resistance to evidence, hasty conclusions, wishful thinking, bias, prejudice, pressure to conform, and every factor that compromises our ability to get to the truth of the matter.

In addition, an open-minded outlook presupposes a conception of knowledge in which reasons and evidence provide justification for truth claims but do so in a fallible manner (Siegel, 2005, 349). As long as we regard our beliefs as infallible, the possibility of objections seeming to us to have merit such that our beliefs might require revision, or outright rejection, simply has no application. In allowing that our beliefs (or at least some of our beliefs) are uncertain, liable to be overturned, and inherently vulnerable, open-mindedness incorporates a kind of intellectual humility that recognizes the 
inappropriateness of dogmatism and finality with respect to our beliefs. It acknowledges the need to discover and learn from the mistakes we may have made, and to recognize that intellectual arrogance may prevent us from being receptive to new ideas (Rescher, 1998, 547).

When we set out to examine the nature of Socratic open-mindedness, however, there is no explicit account in the sources on which to base an interpretation. Nevertheless, embedded in Socrates' lifelong efforts to persuade his fellow citizens to avoid living lives devoid of critical examination, we find an outlook and an approach that bears a close relationship to the ideal of open-mindedness sketched above. The Socratic ideal involves a certain commitment to inquiry and a perspective on human knowledge reflected in a philosophical mission to stimulate critical reflection on the nature of a worthwhile human life. The essential features of the Socratic ideal come into view when we consider two main themes: (i) Socrates' insistence that we must go where the wind of the argument takes us (Republic 394d); and (ii) Socrates' interpretation of the oracle's pronouncement (that no one is wiser than Socrates himself) as meaning that he is acutely conscious of his own ignorance (Apology 23b). In spelling out more fully what these ideas amount to, an ideal of open-minded inquiry gradually emerges.

\section{Socratic Argument}

When Socrates is in prison awaiting execution, Crito urges him to escape, arguing that what Socrates is doing is wrong and amounts to throwing his life away. Socrates responds: "Very well, then, we must consider whether we ought to follow your advice or not. You know that this is not a new idea of mine; it has always been my nature never to accept advice from any of my friends unless reflection shows that it is the best course that reason offers" (Crito 46b). First, then, to follow the argument in the Socratic sense is to make reason and evidence the linchpin of serious inquiry and reflection. Socratic inquiry, like open-minded inquiry, seeks, and is guided by, the best reasons to be found. Socrates draws a sharp contrast between philosophy and oratory, the latter providing only the semblance of argument: "But this method of proof is worthless toward discovering the truth, for at times a man may be the victim of false witness on the part of many people of repute" (Gorgias 471e). Socrates maintains that when we disagree with a position, we need to find good objections, not resort to emotionally charged condemnation (Gorgias 467c). We lose sight of the argument if the discussion is distorted by irrelevant considerations: "Attend only to the argument, and see what will come of the refutation" (Charmides 166e). To follow the argument, then, is to seek, and focus on, reasons that genuinely bear on the matter at hand, so that one is receptive to every relevant consideration.

Second, to follow the argument is to track the fortunes of the inquiry, taking into account alternative and conflicting possibilities, looking at all sides impartially, raising objections and considering replies, paying careful attention to what is to be said for and against the proposition, and trying to ensure that nothing germane to the issue is ignored or excluded. Consider, by contrast, the case of Euthyphro who is about to prosecute his own father for manslaughter, scarcely pausing to wonder whether he might be acting inappropriately in doing so. His supreme confidence that he is right is not justified because he has not carefully weighed the arguments for and against his proposed action. Euthyphro has little interest in what Hume calls "counterpoising arguments." He adopts a dismissive attitude at the outset towards opposing views, assuming that unlike other people he already possesses exact knowledge of the divine law and is far advanced in wisdom: "Why, Socrates, if I did not have an accurate knowledge of all that, I should be good for nothing, and Euthyphro would be no different from the general run of men" (Euthyphro 5a). In failing to think about what is to be said for and against his proposed action in an open-minded manner, he fails to follow the argument.

Finally, to follow the argument is to be willing to follow it through to its conclusion, to be prepared to accept whatever results from the inquiry. This is a requirement of open-mindedness. We follow the argument where it leads; we don't distort the argument to make it support the belief we already favour; and we don't look for ways to explain away unwanted conclusions. Socrates remarks: "If 
he has reason on his side, we will agree with him" (Laches 196c). Our own views and preferences are in the balance in an open-minded exchange of ideas, as Socrates points out: "Let me then tell you our opinion, and if I am wrong you shall set us right" (Laches 198b). In other words, to participate in an open-minded discussion is to accept the risk that our own position may be refuted. We must be ready in the end, however, to adapt ourselves to the facts of the world, as Bertrand Russell puts it, and not close our eyes to the truth because it is unwelcome (Russell, 1956, 47).

We might say, in summary, that the principle of following the argument where it leads embodies a conception of open-mindedness that involves a commitment to reason and evidence as the appropriate basis for the conclusions we draw with respect to what we should believe and how we should act. The emphasis on argument means that Socratic open-mindedness incorporates a critical component which reflects the principle that ideas are only accepted if they are judged to have merit. We follow the argument where it leads, not blindly in the manner of the gullible (Gorgias 493b), but using our critical judgment to assess the merits of the reasons offered. Socratic open-mindedness calls on us to be actively engaged in critical reflection, especially about matters that concern the values we should live by, not simply waiting until our views are challenged or run into difficulties. By looking out for deficiencies and problematic aspects, we may satisfy ourselves that our own beliefs and values can withstand critical scrutiny.

\section{Socratic Ignorance}

Self-criticism is also vital if we are to open our minds to the true nature of human wisdom and its limits, as Socrates makes clear. He interprets the wisdom he is reputed to possess, following the pronouncement of the oracle, as consisting in an acute awareness of his own extensive ignorance that results in a cautiousness with respect to claiming knowledge: "I am only too conscious that I have no claim to wisdom, great or small" (Apology 21b). Such awareness and critical cautiousness constitute the kind of wisdom that sets Socrates apart from others popularly thought to be wise but who have an unwarranted confidence in their own wisdom. In a famous remark, Socrates says of a certain public figure: "It seems that I am wiser than he is to this small extent, that I do not think that I know what I do not know" (Apology 21d). It is his very uncertainty and his awareness that knowledge claims are liable to error that make the process of following the argument so necessary and so worthwhile. He reminds Callicles: "I do not speak with any pretense of knowledge" (Gorgias 506a), indicating that he acknowledges that he may be mistaken and is always ready to be corrected. Gregory Vlastos argues that when Socrates disavows knowledge, he means to reject dogmatic certainty and embrace fallibilism: "He (Socrates) is telling us.... that any conviction he has stands ready to be re-examined in the company of any sincere person who will raise the question and join him in the investigation" (Vlastos, 1971, 10). The outlook described here by Vlastos could equally well be characterized as open-minded.

Consider two examples that convey a Socratic conception of knowledge as provisional and tentative and reflect his insight into the limits of human wisdom. At one moment, Socrates remarks that the arguments that have been put forward to support the view that it is better to suffer evil than to commit evil are as strong as iron; and yet he proceeds immediately to say that he does not claim to know that this is the truth (Gorgias 509a). He further qualifies his conviction that the arguments are conclusive by adding: "at least so it would appear as matters stand" (Gorgias 509a). The implication is that while the view remains secure for now, it is not placed beyond the bounds of subsequent examination. The second example concerns Socrates' concluding words to Crito, having rejected the suggestion that he should try to escape from prison: "I know that anything more which you may say will be in vain. Yet speak, if you have anything to say" (Crito 54d). That final invitation to Crito clearly conveys the idea that a view, however strongly supported, is never quite beyond the reach of further examination. 
Conscious of his ignorance, Socrates can invite objections to his views in the spirit of openness to correction, as he does with Crito, and he is able to acknowledge the possibility of being refuted and having to revise his position. Socrates approaches the issues he examines as someone who is genuinely puzzled and perplexed, confident only that the confidence of others is not based on any critical review of the relevant arguments, and determined not to settle for anything less than views which can withstand the test of critical scrutiny. In all of this, Socrates sets an example to others of an openminded outlook that they might emulate and which he is trying to foster.

The image before us, then, is that of a philosopher devoting himself to persuading his fellow citizens to submit important beliefs and decisions to critical examination with a view to determining which ones are justified. Such examination will not be genuine unless one is disposed to look at one's beliefs, assumptions, and values in an open-minded way. A compelling portrait of Socrates in the history of philosophy, mirrored in the account above, presents him as a philosophical champion and celebrated exemplar of open-mindedness. But is this portrait overly flattering? Does it brush over certain problematic aspects? Are there qualifications and reservations to be noted when we speak of Socratic open-mindedness? What could be more appropriate at this stage than to subject our account of Socratic open-mindedness to Socratic examination?

\section{Socrates Examined}

\section{Is Socrates a skeptic?}

Contrary to the view that Socrates views knowledge as provisional and tentative, at the same time acknowledging his own extensive ignorance, it is sometimes thought that he favours a more extreme position, one closer to skepticism involving "radical doubt towards all claims to knowledge" (Simpson, 2006, 140). Socrates' interpretation of the oracle's meaning might seem to disavow knowledge completely: "The wisest of you is he who has realized, like Socrates, that in respect of wisdom he is really worthless" (Apology 23b). In the same context, Socrates says categorically: "He thinks he knows something which he does not know, whereas I am quite conscious of my ignorance" (Apology 21d). In addition, the Socratic dialogues end in failure as far as answering the central question in each dialogue is concerned, indicating an inability in these cases to arrive at knowledge, creating perhaps the suspicion that cumulative failure means that knowledge simply cannot be gained. Recall again the passage cited earlier from the Gorgias, where Socrates confesses not to know that a certain conclusion is true even though what he calls the most compelling arguments have been put forward to support it. If powerful arguments such as these have not succeeded in producing knowledge, could any argument be successful? In this way, the notion of a Socratic skepticism begins to take root.

It is important, however, to distinguish a skeptical attitude with respect to whether or not knowledge has been attained, or can readily be attained, from philosophical skepticism about the very attainability of knowledge. Certainly, Socrates often reveals a profoundly skeptical attitude when it is too quickly assumed that someone possesses knowledge. Similarly, he displays at times a skeptical attitude as to whether progress has been made in the conversations that take place: "You and I are behaving absurdly in this discussion, for throughout the time of our argument we have never ceased returning in circles to the same point in a constant failure to understand each other's meaning" (Gorgias $517 \mathrm{c})$.

This kind of skepticism, however, is no threat to open-mindedness. Socratic skepticism is, to use Hume's phrase, very much a mitigated form of skepticism that is practised out of a concern for truth. To think that we have been unsuccessful in our attempts to reach a true conclusion, or to think that we have failed to communicate our ideas to each other in the discussion, is a reason to redouble our efforts at open-minded inquiry -- to examine the arguments and evidence with greater care, and to 
listen more intently and effectively to what the other person is saying. As Priscilla Sakezles puts it, Socrates "does not proclaim knowledge to be impossible, but merely is humble about his own and continues the search, always critically examining any knowledge claim" (Sakezles, 2008, 13). She concludes that Socrates "is not the sort of dogmatic and self-contradicting skeptic that he is often made out to be" (Sakezles, 2008, 13).

If Socrates were thought to subscribe to the view that knowledge is completely unattainable, that it necessarily eludes our best efforts to secure it, no value could be found in open-minded reflection. Why revise our beliefs if our epistemic position cannot be improved? Why follow the argument if true conclusions must inevitably elude us? Why examine our assumptions if better ideas are not to be found? It is unclear how we could reconcile this interpretation with Socrates' own comments. Referring to the inconclusive outcome of his debate with Protagoras, Socrates remarks: "For my part, Protagoras, when I see the subject in such utter confusion, I feel the liveliest desire to clear it up" (Protagoras 361c). Similarly, towards the end of the Euthyphro, Socrates says: "And so we must go back again, and start from the beginning to find out what the holy is" (Euthyphro 15c). Far from pessimism and outright skepticism, we find renewed determination to make headway.

Socrates' commitment to the pursuit of truth is also clearly evident when he is unwilling to continue the discussion if the other person is not inquiring seriously. He says to Callicles: "You can no longer properly investigate the truth with me, if you speak contrary to your opinions" (Gorgias 495a). As we learn at his trial, Socrates is ready to risk his life in order to continue to engage his fellow citizens in discussion, berating them over their indifference to reflection and inquiry: "Are you not ashamed that you give your attention to acquiring as much money as possible, and similarly with reputation and honour, and give no attention to truth and understanding and the perfection of your soul?" (Apology $29 \mathrm{e})$. None of this makes sense on the view that Socrates believes that the search for truth and knowledge is pointless because it is doomed to failure.

\section{Is Socratic teaching open-minded?}

What we have come to think of as Socratic teaching at its best forgoes direct instruction and seeks to provoke puzzlement and uncertainty by way of questions and challenges leading on to fresh insights and greater understanding and a desire to pursue the truth. Ideally, it is a provocation to open-minded inquiry, and it is most effective when the manner of the teacher genuinely exemplifies the virtue of open-mindedness in his or her own practice. Socrates denies that he is a teacher because he is not an expert on the nature of virtue and he lacks the kind of understanding and knowledge that expertise requires and that makes teaching possible in his view (Apology 20c). Rather he describes himself as a fellow inquirer engaged with others in the search for truth (Charmides 165b), where his strategy is to raise questions and to engage others in discussion and argument.

Certainly, there are aspects of Socrates' manner and practice that do clearly convey an attitude of open-mindedness, such as disclaiming certainty, reminding people that his own views are not universally accepted, confessing that he is himself confused, listening to objections, giving others a chance to express their ideas in their own words, pointing out the need to go on learning, and so on. Is Socrates, however, really an earnest inquirer after truth? Those he questions do not always see it this way, complaining that his main purpose is simply to show that they are mistaken. He is, some say, "always weaving the meshes of an argument, selecting the most difficult point, and fastening upon details instead of grappling with the matter in hand as a whole" (Hippias Minor 369b). Similarly, Critias says: "You are only doing what you denied that you were doing just now, trying to refute me, instead of pursuing the argument" (Charmides 166d). Moreover, to what extent are his own views open to challenge? Socrates rigorously examines the views of others, but does he engage in self-examination? Again, is Socrates as open to alternative ideas as open-mindedness would require? Emily Wilson finds

him positively parochial and narrow and says bluntly that "Socrates is anything but open-minded in his ideas about how life should be examined" (Wilson, 2008, 53). 
In response to these criticisms, it is helpful to view Socratic refutation as a necessary preliminary to further inquiry when people are stubbornly committed to unexamined views and display an unwarranted confidence in their own wisdom. Speakers need to acknowledge that their assumptions are problematic and this means that their convictions must be disturbed. The distinction Critias relies on between refutation and following the argument is misleading. If Critias is ever to follow the argument, either with Socrates or on his own, an uncomfortable state of uncertainty is an important, but temporary, stage in an overall process of coming to realize that there is a genuine problem to be faced. It is true that Socratic discussions do not always have this desired result (Nehemas, 1992, 295), but it remains plausible to suggest that this is indeed Socrates' aim. He says plainly, at the end of an inquiry that proves inconclusive: "I cannot advise that we remain as we are" (Laches 201a). There is no reason to believe, as some critics suggest, that the Socratic method is "designed to leave the hapless interlocutor refuted by a contradiction and acutely aware of her confusion and ignorance" (Leigh, 2007, 318). The resistance Socrates meets in his fellow discussants is, however, a valuable reminder that openmindedness is not easily attained.

With respect to the second concern, it must be admitted that generally it is the views of his interlocutors that are under direct scrutiny in the dialogues. It is Euthyphro, Crito, Critias, and Laches who are on the defensive, forced into the unenviable role of having to answer Socrates' searching questions. Socrates controls the inquiry, eliciting answers that are quickly exposed to counter-examples, and moving the discussion on to the questions he is really interested in. Before we concede too quickly, however, that Socrates evades self-examination, several points need to be made.

First, Socrates extends a regular invitation to others to challenge his views and to refute them if they can. He describes himself as "one of those who would gladly be refuted if anything I say is not true, and would gladly refute another who says what is not true, but would be no less happy to be refuted myself than to refute, for I consider that a greater benefit (Gorgias 458a). Second, the views which come to grief are not always those put forward by those whom Socrates cross-examines. Socrates himself introduces the view that good people are friends with good people like themselves (Lysis 215c) and begins to set out what can be said in support of it only to come to a point where he admits that they seem to be on the wrong track. This helps to reinforce the idea that it is the argument that matters, and that anyone, Socrates included, may be attracted at first to a mistaken view. Thirdly, as Roslyn Weiss argues, in cross-examining others, there is necessarily also an aspect of self-examination (Weiss, 2006, 248). She points out that, in trying to show that a contrary view is problematic, the danger is that Socrates' own view might begin to seem less secure. As Socrates observes, "it may turn out that both I who question and you who answer are equally under scrutiny" (Protagoras 333c), In many cases, of course, Socrates admits at the end of the dialogue that he is himself equally perplexed.

Finally, we may consider Emily Wilson's very negative assessment. She claims, for example, that Socrates shows no interest in non-Athenian cultures. In the Apology, however, Socrates points out that he might have been able to defend himself more adequately if more time were allowed for capital trials as happens in other countries (Apology 37b). Wilson claims that Socrates is hostile to alternative ways of understanding the world, such as through poetry, and yet it seems clear that Socrates believes that much wisdom is to be found in poetry even if the poets themselves are not able to explain their own poems (Apology 22c). Wilson complains that Socrates doesn't consider abandoning all of his views or adopting a different method of inquiry. None of this establishes a lack of open-mindedness. To commit oneself to a particular methodology to see what it might yield is not to dismiss other approaches. Moreover, it would not be a mark of open-mindedness to simply abandon all of one's important beliefs even if this were possible. One would need some reason to regard them as dubious and this is what Socrates is attempting to discover. 


\section{Does Socrates foster skepticism in others?}

Socratic discussions typically induce perplexity, confusion, and uncertainty. Those who admire the open-mindedness in Socrates' approach view such bafflement as a teachable moment. Caught off balance, we feel the need to take a second look at our beliefs and, in this way, Socratic refutation is thought to foster open-mindedness in others.

Not everybody, however, views the Socratic enterprise in this positive light. George Watson comments: "The Socratic challenge is hopeless because it is endless; it leaves all the big questions looking ultimately insoluble.... [but] no amount of talking would help us agree on definitions of virtue or justice, and aporia can easily turn into a state of mind little different from total skepticism" (Watson, $2005,79)$. The accusation here is that Socrates induces skepticism in his listeners, causing them to close their minds to the knowledge they already possess and creating in them a state of mind that makes inquiry seem meaningless (cf. Brownhill, 2002, 77). Open-mindedness, it is alleged, vanishes in those infected with the Socratic virus, leaving only a sense of emptiness (Lear, 1998).

The Socratic challenge, however, need not have these consequences. The questions Socrates raises are important because our thoughts about justice and morality are often confused and our inability to explain these ideas reveals our confusion. Suppose we think, along with Thrasymachus, that justice is what serves the interests of the powerful (Republic 338c). That is a conception of justice with potentially harmful consequences for human society, and it is one on which we can surely improve. Watson fails to recognize the way in which philosophical questions of the sort raised by Socrates help to open our minds to new possibilities. It would be hard to improve on Bertrand Russell's verdict, with respect to philosophical questions in general, that "these questions enlarge our conception of what is possible, enrich our intellectual imagination, and diminish the dogmatic assurance which closes the mind against speculation" (Russell, 1973, 93-4).

Watson claims that the unending Socratic demand for explanations and justifications of basic moral concepts causes us to close our minds to the evident fact that everyone possesses a great deal of moral knowledge, an inherent moral sense, and generous human affections. He comments: "The targeting of moral knowledge, the determination of Western philosophy since Socrates to defame it or to demand some heavenly authority like the Mosaic law to certify it, looks perverse and unaccountable. Nobody asks to know why he should believe the two-times table. You see that it is so. No harder, surely, to see that murder is wrong" (Watson, 2005, 85).

This objection has little plausibility. Socrates did not pause to engage in endless reflection when it was proposed that the naval commanders should be tried as a group rather than individually (Apology 32b). He was the only member of the executive to vote against this proposal. A full account of the nature of justice might remain elusive but this never causes him to waver in his profound moral conviction that it is unjust to deny someone a fair trial. It is equally bizarre to say, as Watson does, that under the shadow of Socrates, it is difficult to recognize that human affections are real as well as agreeable. Are we to think, for example, that concern for another human being is not at play when Socrates refuses to go along with the order to arrest Leon of Salamis for summary execution? (Apology 32c). Both of these decisions put Socrates' own life on the line, and he leaves us with a powerful demonstration that philosophical questioning and open-mindedness are by no means incompatible with deep convictions and strong human feelings.

\section{Does Socrates recognize the need to listen to experts?}

One of Socrates' fundamental principles is that we need to think for ourselves about important matters; the unexamined life is not worth living. In recent times, however, we have come to a new appreciation of the fact of epistemic dependence. As John Hardwick reminds us, we are simply unable to pursue 
epistemic autonomy successfully across the board (Hardwick, 1985, 340). We cannot discover for ourselves, and we cannot always critically assess, much of what we know. I know that the age of the earth is about 4.5 billion years but I have no ability to critically review the evidence for this proposition. I doubt that I could even follow the argument. Still, we rightly say we know in such cases because we have good reason to believe that the experts have good reason to believe that such and such is true. We might say that our open-mindedness in such cases amounts to accepting what the experts tell us but such acceptance is not uncritical (Siegel, 1988, 3).

Socrates often takes a dim view of many claims to expertise. He doubts, for example, that anyone is an expert in perfecting the human and social qualities, although many, like Protagoras, believe they do have such expertise. He concludes also that the politicians, the poets, and the craftsmen are by no means as wise and expert as they think they are (Apology 21b-22d). They have no sense of the limited extent and sometimes non-existence of their supposed expertise. Socrates cultivates a healthy skepticism with respect to such claims. But does he take such skepticism too far? Does he do justice to the idea of epistemic dependence and the need to be open-minded enough to defer to what genuine experts have to say?

Two considerations put the matter in a more favourable light. First, Socrates does clearly recognize the fact of genuine expertise and the need to avail ourselves of it. For example, he remarks: "When there is a gathering in the city to choose doctors or shipwrights or any other professional group, surely the rhetorician will not then give his advice, for it is obvious that in each such choice it is the real expert who must be selected" (Gorgias 455b). The implication is that we must be receptive to the advice of genuine, not pseudo, experts. Second, Socrates should not be seen as urging non-experts to answer expert questions for themselves, but rather as urging them to try to determine whether the person has the expertise they claim to have, whether the experts are in agreement with each other, and whether the question is one for experts at all. Socrates issues a warning before we place ourselves in the hands of self-proclaimed experts: "Knowledge cannot be taken away in a parcel. When you have paid for it you must receive it straight into the soul. You go away having learned it and are benefited or harmed accordingly. So I suggest we give this matter some thought, not only by ourselves, but also with those who are older than us" (Protagoras 314b).

\section{Conclusion}

Is Socratic open-mindedness capable of providing guidance and illumination today? Consider the notorious case of Dr. Charles Smith, the former Ontario pediatric pathologist at the Hospital for Sick Children in Toronto. An international panel of experts reviewed his work in 2006 and Smith was found to have made significant errors in 20 child death cases from 1992 to 2002, resulting in many wrongful convictions and serious miscarriages of justice. Louise Reynolds spent two years in custody, awaiting trial, accused of having stabbed her daughter to death with scissors or a knife. In fact, the girl had died of injuries inflicted by a bull terrier. William Mullins-Johnson spent twelve years in prison convicted of raping and murdering his four year old niece. There had been no rape at all and the girl had died of natural causes. How do these shocking cases relate to the ideal of open-mindedness associated with Socrates?

First, Smith lacked any sense of Socratic wisdom, that fundamental insight into one's own ignorance that breeds a self-critical attitude. Smith had every reason, moreover, to be conscious of his own limitations, knowing that he lacked any formal training in forensic pathology. Testifying in court, however, he was dogmatic and arrogant, often ridiculing genuine forensic experts who disagreed with him. The complete absence of intellectual humility led him to dismiss alternative explanations and diagnoses, a point that was noted as early as 1991 by Justice Patrick Dunn who observed that "it would behoove Dr. Smith in making such an important decision as a diagnosis of shaking that would lead to a manslaughter charge to show he seriously considered possibilities other than shaking" (quoted in Boyle, 
2007). It was also revealed at the public inquiry in 2008 that Smith refused to reconsider his opinion even when confronted with contradictory medical evidence (Blackwell, 2008).

Second, once Smith had achieved a certain position and reputation, his supposed expertise was not held to the kind of scrutiny by others that might have led to mistakes being detected and injustices prevented. Smith's celebrity status as Canada's leading pathologist in cases of child death seemed to silence the kind of skeptical questioning of expertise Socrates encouraged. It is not as if there were no warning signs. There was, of course, the 1991 case just mentioned in which Justice Dunn was highly critical of Smith and where numerous defence experts rejected Smith's conclusions. Again, in 1994, a complaint was made about Smith to the College of Physicians and Surgeons of Ontario, but an investigation was blocked by the coroner's office. The conclusion seems inevitable that those who were responsible for overseeing his work were not willing to consider the possibility that his work was flawed, a reluctance no doubt encouraged by Smith's own unhesitating certainty that his conclusions were correct. Some colleagues and superiors later claimed not to have been aware of the complaints about Smith that were in wide circulation, but if this is true it raises the suspicion that they did not want to know.

Third, a protocol was issued in April 1995 by Dr. James Young, former chief coroner of Ontario, stating that it was extremely important that all members of the investigative team 'Think Dirty.' This policy reflected, and in turn helped to perpetuate, a climate of opinion at the time in which the person who was with the child when the child died was immediately under suspicion. Later experts testified that Smith suspected child abuse in a number of cases where the evidence itself gave no grounds whatsoever for that suspicion. This resulted in many child-death cases being investigated in a prejudicial manner, the assumption at the outset being that the parents or the child-minder were probably guilty. In these circumstances, the Socratic ideal of "following the argument", where an attempt is made to draw the conclusions warranted by the evidence, degenerated into looking for evidence that would incriminate those under suspicion. Recall, in the context of this case, that the early 1990s was also the time when the most absurd claims of Satanic ritual abuse of children were widely taken at face value, with the result that numerous parents and others were charged on the basis of dubious evidence and in an atmosphere where guilt was assumed. Socrates alerts us to these dangers at his own trial when he remarks how difficult it is going to be for him to gain a fair hearing: "I must try, in the short time that I have, to rid your minds of a false impression which is the work of many years" (Apology 19a). An open-minded response from the jury was impeded by various long-standing assumptions about Socrates' character and intentions.

"Mankind can hardly be too often reminded that there was once a man called Socrates, between whom and the legal authorities and public opinion of his time there took place a memorable collision" (Mill, 1977, 84). I have taken Mill's words to heart and offered one more reminder. If Socratic open-mindedness had been able to influence those responsible for these shameful events in Ontario, it might have done much to temper the excesses of blind conviction and to restore the notion of genuine inquiry. The only way to avoid such results is to keep the central meaning and value of the ideal alive in our consciousness so that it carries over into our everyday lives. It will be all to the good, therefore, if open-mindedness is seen by teachers as central to their educational aims. A philosophical ideal cannot fulfill its purpose if it remains an inert idea.

\section{Acknowledgements}

This paper was presented at the Open-mindedness and the Virtues in Education Conference at Mount Saint Vincent University, October 2-4, 2008. It is dedicated to the memory of Terry McLaughlin. 


\section{References}

Boyle, T. (2007). Signals missed as errors piled up. The Toronto Star, December 10.

Blackwell, T. (2008). Dr. Smith convinced police that woman killed her child: inspector. National Post, January 14.

Brownhill, R. (2002). The Socratic method. In Peter Jarvis (Ed.), The Theory and Practice of Teaching. London: Kogan Page, 70-78.

Haack, S. (1997). Science, scientism, and anti-science in the age of preposterism. Skeptical Inquirer $21(6 \mathrm{P}, 37-42,60$.

Haack, S. (2005). The ideal of intellectual integrity, in life and literature. In New Literary History 36 (3), 359-73.

Hardwick, J. (1985). Epistemic dependence. Journal of Philosophy 82(7), 335-49.

Hare, Wm. (2007). What is open-mindedness? In William Hare and John P. Portelli (Eds.), Key Questions For Educators. San Francisco: Caddo Gap Press, 21-24.

Hare, Wm. (2009). What open-mindedness requires. Skeptical Inquirer 33(2), 36-39.

Hume, D. (1955). An Enquiry Concerning Human Understanding. In C. W. Hendel, Jr., Hume Selections New York: Charles Scribner's Sons.

Lear, J. (1998). The examined life. The New York Times, October 25.

Leigh, F. (2007). Platonic dialogue, maieutic method and critical thinking. Journal of Pbilosopby of Education 41(3), 309-23.

Mill, J. S. (1977). On Liberty. Harmondsworth: Penguin Books.

Nehemas, A. (1992). What did Socrates teach and to whom did he teach it? Review of Metaphysics 46(2), 279-306.

Rescher, N. (1998). Fallibilism. In Edward Craig (Ed.), Routledge Encyclopedia of Philosophy Vol. 3. London: Routledge, 545-48.

Rorty, R. (1989). Contingency, Irony, and Solidarity. Cambridge: Cambridge University Press.

Rorty, R. (2007). A rejoinder to Bela Eghed. Available online: http://www.eurozine.com/articles/2007-08-07-rorty-en.html

Russell, B. (1956). Portraits From Memory. London: George Allen and Unwin.

Russell, B. (1973). The Problems of Philosophy. London: Oxford University Press.

Sakezles, P. (2008). Socratic skepticism. Skeptic 14(2), 12-13.

Scheffler, I. (1983). The moral content of American public education. In Henry Giroux and David Purpel (Eds.), The Hidden Curriculum and Moral Education Berkeley: McCutchan, 309-17.

Siegel, H. (1988). Rationality and epistemic dependence. Educational Philosophy and Theory 20(1), $1-6$.

Siegel, H. (2005). Truth, thinking, testimony and trust: Alvin Goldman on epistemology and education. Philosophy and Phenomenological Research 71(2), 345-66.

Simpson, T. L. (2006) Is Socrates the ideal democratic citizen? Journal of Thought 41(4), 137-56.

Vlastos, G. (1971) The paradox of Socrates. In Gregory Vlastos (Ed.), The Philosophy of Socrates. New York: Anchor Books, 1-21.

Watson, G. (2005). Socrates' mistake. American Scholar 74, pp. 78-87.

Weiss, R. (2006). Socrates: seeker or preacher? In Sara Ahbel-Rappe and Rachana Kamtekar (Eds.),A Companion to Socrates. Malden, MA: Blackwell, 243-53.

Wilson, E. (2008). What is wrong with Socrates? The Philosopher's Magazine 41, 49-54.

\section{About the Author}

William Hare is Professor Emeritus at Mount Saint Vincent University. His books include Openmindedness and Education (1979), In Defence of Open-mindedness (1985), and What Makes A Good Teacher 
(1993). He co-edited Key Questions For Educators (2007). He has published 100 articles and chapters, most recently in International Journal of Applied Philosophy, Journal of Philosophy of Education, Philosophy Now, and Think. He was President of CPES from 1984-6, and Editor of Paideusis from 1992-96.

Email: william.hare@msvu.ca. Website: williamhare.org

\section{Notes}

With one exception, all translations are taken from E. Hamilton and H. Cairns (eds.), The Collected Dialogues of Plato Princeton University Press, 1980. The quotation from Crito 54d is from Plato, Euthyphro, Crito, Apology and Symposium Chicago: Gateway, 1953.

The Report of the Inquiry into Pediatric Forensic Pathology in Ontario, prepared by Commissioner Stephen T. Goudge, was released on October 1, 2008. See: www.goudgeinquiry.ca 